\title{
Doktoravhandling om selvmordsforsøk i et problemløsningsperspektiv
}

\author{
Ved Gudrun Dieserud
}

\section{N y doktoravhandling fra Psykologisk institutt, U i0 gir bidrag til økt forståelse for samspill mellom faktorer i} utviklingen av suicidal atferd. Resultatene viser: 1) 53,5\% reduksjon i selvmordsforsøksraten i B ærum over en 12-årsperiode. 2) Selvmordsforsøk knyttes ikke bare til depresjon/håpløshet, men også til sviktende problemløsningsevne uavhengig av depresjon. 3) U like negative livshendelser i barndommen gir ulike psykologiske problemer hos voksne mannlige og kvinnelige selvmordsforsøkere. 4) Liten tiltro til egen problemløsningsevne, eller svak mestringsforventning ( self-efficacy) er en viktig prediktor for gjentagelse av selvmordsforsøk.

\section{Suicide attempt: Unsolvable lives?}

Dette er tittelen på artikkelforfatterens doktoravhandling, utgått fra Statensinstitutt for folkehelse og Psykologisk institutt, $\mathrm{U}$ iO. A vhandlingen omhandler ulike aspekter ved sel vmordsforsøk, med spesiell vekt på kognitive funksjoner. A rbeidet tar utgangspunkt i psykologisk forståelse av selvmordsatferd, og har som hovedmålsetting å bidra med kunnskap om samspill mellom enkeltvariabler som tidligere er funnet å samvariere med suicidforsøk . A rbeidet springer ut av mangeårig klinisk arbeid med oppfølging av selvmordsforsøkere i Bærum, og resul tatene fra delundersøkelsene kan på ulike nivåer anvendes til å styrke mål rettet intervensjon overfor denne gruppen.

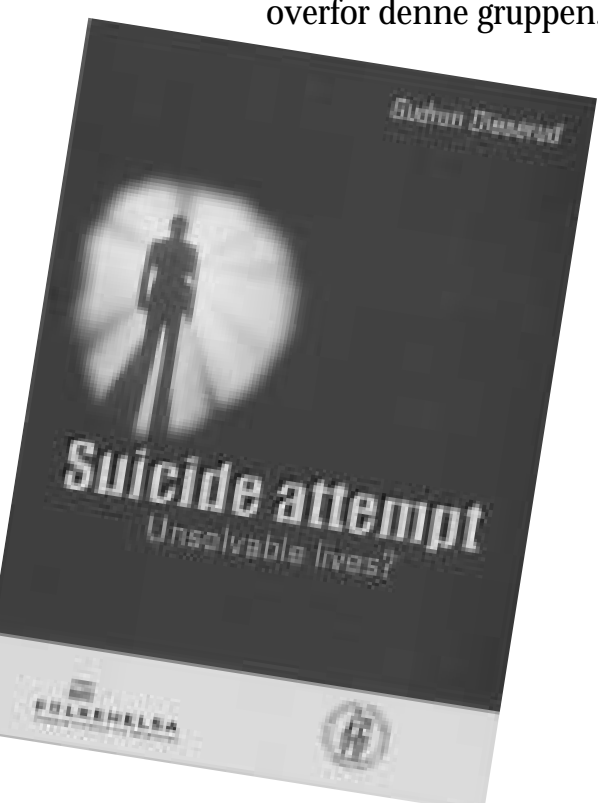

I Prosjektplan og

handlingsplan mot selvmord 1994-1998 (Statens hel setilsyn skriftserie 4-95) legges det vekt på "systematiske modellforsøk med behandlingstiltak og oppfølgingstiltak" som forebyggingsstrategi, uten at dette gis spesifikt faglig innhold. I og med at det hersker ulike oppfatninger av om, og i så fall hvordan, selvmord kan forebygges, er suicidologien preget av mangel på enhetlig kunnskap. Videre er de fleste forebyggingsmodeller ikke utviklet spesielt i forhold til selvmordsatferd, men er primært basert på modeller utviklet i kommunehelsetjenesten eller den psykiatriske spesialisthelsetjenesten. Derfor er det stort behov for forskning som kan anvendes i relasjon til både forebygging, tidlig intervensjon og behandling.

U tvikling av modeller for selvmordsforebygging bør ta utgangspunkt $\mathrm{i}$ :

- Kartlegging av problemets omfang (selvmords- og selvmordsforsøksepidemiologi)

- Identifisering av høyrisikoindivider (sosiale, demografiske, psykologiske, psykiatriske karakteristika)

- Kartlegging av lokale ressurser

- Etablering av tiltak som raskt kan settes inn overfor høyrisi koindivider (tidlig intervension).

A vhandlingens ulike deler gir på forskjellige nivåer bidrag til disse grunnleggende forebyggingselementene.

\section{Selvmordsforsøk og selvmord i Barum over en 12-ărsperiode}

I første artikkel presenteres epidemiologiske data over selvmordsforsøk og selvmord i Bærum kommune over en 12årsperiode (1984-1995). Det ble registrert 1446 sel vmordsforsøk for 1031 sykehusbehandlete selvmordsforsøkere i perioden, $64 \%$ av pasientene var kvinner. Totalt var ca. $50 \%$ under 35 år. G jennomsnittsraten for kvinner var $149 / 100000$, for menn $90 / 100000$, samlet $121 / 100000$, hvilket er lavere enn sammenlignbare tall fra ulike W H O/EU RO -publikasjoner. Resultatene viser at selvmordsforsøksraten ble redusert med 53,5\% i løpet av observasjonsperioden. Selvmordsraten for perioden var noe høyere i Bærum enn i resten av landet, spesielt blant kvinner. Blant selvmordsforsøkerne var det 2,4\% som tok sitt liv etter gjennomsnittlig 6,5 år, noe som er relativt lavt. Studien gir grunnlag for å anta at oppfølging etter selvmordsforsøk i henhold til Bærumsmodellen kan ha bidratt til nedgang i antall selvmordsforsøk. Selvmordstallene er for små til at det kan trekkes konklusjoner.

\section{Årsaksmodell for selvmordsforsøk}

I avhandlingens andre artikkel presenteres en årsaksmodell for selvmordsforsøk. Den teoretiske rammen for arbeidet er knyttet til en sårbarhet-stressmodell for depresjon og suicidalitet, der antagelsen er at lav selvaktelse ( self-esteem) lav tiltro til egne evner (self-efficacy), en somhet og separasjon/skilsmisse vil utgjøre sårbarhetsfaktorer for utvikling av depresjon, håpløshet, dårlig problemIøsningkapasitet, selvmordstanker og selv mordsatferd. Tidl igere forskning har vist sprikende resultater, spesielt i forhold til om dårlige problemløsningsevner er knyttet til en depressiv tilstand eller om suicidale individer er preget av sviktende problemløsningsevner uavhengig av depresjon. Ved hjelp av strukturell ligningsmodel lering viser resultatene at det går to veier (stier) til selvmordsforsøk: en fra ensomhet og lav selvaktelse som fører til depresjon ( som også er påvirket av separasjon/skilsmisse) via håpløshet og selvmordstanker til selvmordsforsøk. Den andre veien går fra lav tiltro til egne evner og lav selvaktelse, medieres gjennom lav generell problemløsningsevne og dårlig evne til løsning av mellommenneskelige problemer til selvmordsforsøk. M odellen viser god tilpasning til data, og resultatene peker på betydningen av å arbeide både med kognitive og emosjonelle faktorer når man arbeider med selvmordsforsøkere. 


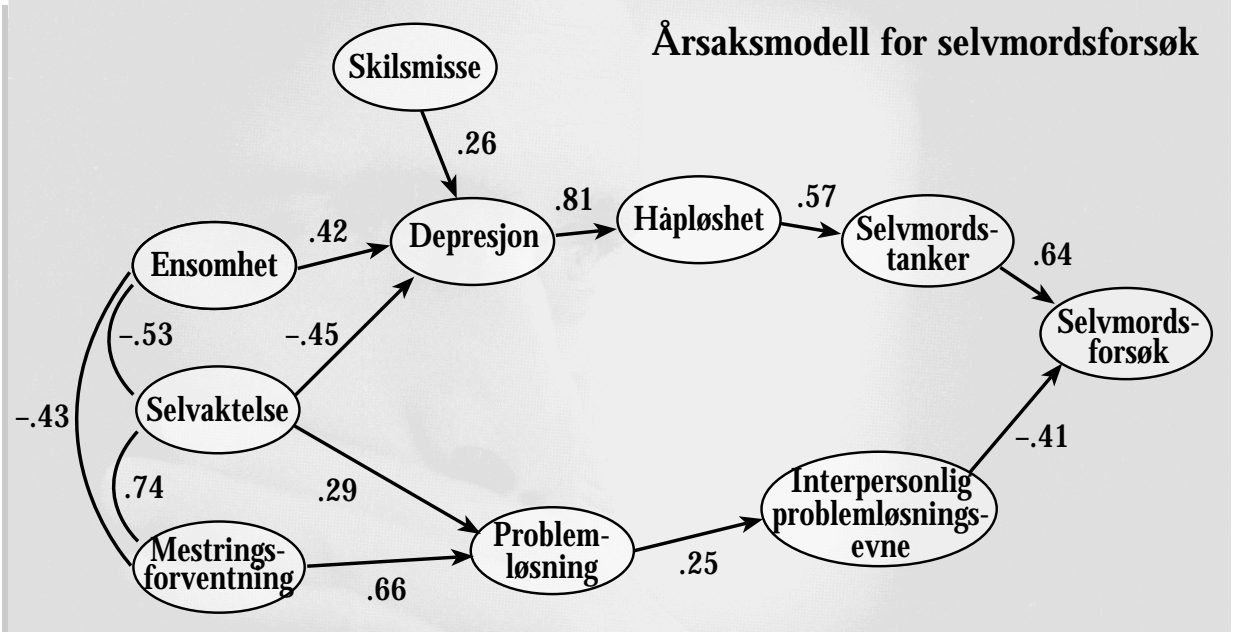

\section{Negative livshendelser i barndommen}

I avhandlingens tredje artikkel var formålet med arbeidet å studere betydningen av negative livshendelser i barndommen (tap av foreldre; foreldres psykiske problemer; foreldres psykiske, fysi ske eller seksuelle misbruk av barnet) på senere selvmordsforsøk. Dette er en case-controlundersøkelse med 271 matchete kontroller til 50 selvmordsforsøkere. R esultatene av den betingete logistiske regresjonsanaIysen viste at risiko for selvmordsforsøk var knyttet til både negative livshendelser i barndommen og til pykologiske problemer som voksen. Dessuten viste resultatene at effekten av livshendel sene ble del vis mediert gjennom de psykologiske problemene, og det fremkom forskjellige medieringsmønstre for menn og kvinner. For menn utviklet suicidal itet seg fra barndomsopplevelsen av foreldres psykiske problemer til lav selvfølelse som voksen, når andre relevante faktorer ble kontrollert (alkohol problemer, tidligere selvmordsforsøk, depresjon, egenvurdert problemløsningsevne). For kvinner var selvmordsforsøksrisiko signifikant knyttet til barndomsopplevelser av forel dreovergrep, egen depresjon og alkohol problemer som voksne. Tidligere selvmordsforsøk ga også betydelig forhøyet risiko for indexforsøket.

\section{Prospektiv undersøkelse av selvmordsforsøkere}

A vhandlingens fjerde artikkel omhandler en prospektiv undersøkelse av 50 selv- mordsforsøkere, intervjuet for annen gang ca. 1 1/2 år etter indexforsøket. $M$ ålsettingen med undersøkelsen var å identifisere risikofaktorer for gjentagelse av selvmordsforsøk innenfor denne tidsrammen. $A v$ de faktorene som ble inkludert i den logistiske regresjonsanalysen (depresjon, håpløshet, mestringsforventning, selvaktelse, egenvurdert problemløsningsevne, interpersonlig problemløsningsevne, medisinsk risiko, suicidal intensjon, tidligere selvmordsforsøk, alder og kjønn), var det bare svak mestringsforventning (self-efficacy) som viste prediktiv verdi i forhold til de 8 av 50 selvmordsforsøkere som gjentok forsøket.

Resultatene fra de fire delundersøkelsene bør ha relevans både for forebygging og tidlig intervensjon/behandling.

R esultatene styrker tidligere undersøkelser som viser betydningen av å arbeide med kognitive dysfunksjoner i tillegg til emosjonelle problemer.

\section{Referanse}

Dieserud G. Suicide A ttempt. U nsolvable Lives? Doktoravhandling. O slo: Psykologisk institutt, U niversitetet i 0 slo, 2000.

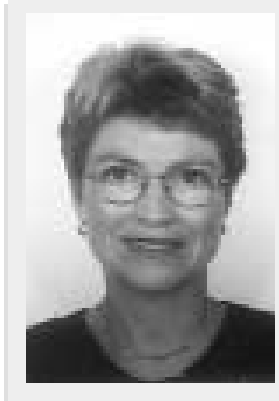

G udrun D ieserud arbeider som psykolog i Bærum kommune og forsker på Folkehelsa. $\mathrm{H}$ un er faglig ansvarlig for det kommunale selvmordsforebyggende team, som arbeider med oppfølging av selvmordsforsøkere og etterlatte etter selvmord.

\section{Ny bok}

Jan Beskow (red.):

Självmord och självmordsprevention. O m livsavgjørande ögonblick. L und: Studentlitteratur, 2000

Jan Beskows navn er en garanti for bokens kvalitet. $\mathrm{H}$ an har selv skrevet de fleste kapitlene. De omhandler sel vmordsproblemets mange ansikter, definisjoner og modeller, det svenske nasjonale program, epidemiologi, folkehel se og sel vmordsforebygging, samtale med selvmordsnære mennesker, etikk, personalutvikling, historie mv. O m strategier for selvmordsforebygging har Danuta W asserman skrevet, om forebyggende arbeid blant barn og ungdom $\mathrm{A}$ gnes $\mathrm{H}$ ultén, om suicidale kriser og psykiske forstyrrelser Bo R uneson og om eldre M argda W aern. $M$ an har i Sverige et meget rikt miljø for selvmordsforebyggen de arbeid, med erfaringer systematisert over mange år. Boken bære preg av dette. Den vil utvilsomt representere et aktivum også i det selvmordsforebyggende arbeid i vårt land.

N ils R etterstøl

forts. fra s. 9

\section{Referanser}

Gjærum B., G røholt B. \& Sommerschild H M estring som mulighet i møte med barn, ungdom og foreldre. O slo: TA N O, 1998

G røholt, B, Ekeberg, $\mathrm{O}, \mathrm{H}$ aldorsen, $\mathrm{T}$. A dolescents hospitalised with deliberate self-harm: the significance of an intention to die. European Child \& A dolescent Psychiatry 2000; 9: 244-54.

Grøholt B., Ekeberg O., W ichstrøm L.\& H aldorsen $T$. Young suicide attempters: a comparison between a clinical and an epidemiological sample. Journal of the A merican A cademy of $C$ hild and A dolescent Psychiatry 2000; 39: 868-75.

Rossow I, W ichstrøm L. Parasuicide and use of intoxicants among $\mathrm{N}$ orwegian adolescents. Suicide and Life-threatening Behaviour 1994; 24: 174-83.

Spirito A., Brown L., O verholser J. \& Fritz G A ttempted suicide in adolescence: a review and critique of the litterature. Clinical Psychological Review 1989; 9: 335-63.

Sprague T. Clinical management of suicidal behaviour in children and adolescents. C linical Child Psychology and Psychiatry 1997; 2: 113-23. 